\title{
Editorial
}

\section{Enhancing the effectiveness of the 21st century Board of Directors: Part II}

International Journal of Disclosure and Governance (2013) 10, 287-294. doi:10.1057/jdg.2013.26

Welcome to the second of two issues of this Special Edition of the International Journal of Disclosure and Governance entitled 'Enhancing the Effectiveness of the 21st Century Board of Directors'. We have eight articles herein, including a mixture of academic and practitioner articles, qualitative and quantitative research, gender and geography, the application to emerging and developed economies, new and emerging research by doctoral candidates and their supervisors and subject matter areas.

The focus of the first issue, Volume 10 Number 2, May 2013, was on three areas that are critically important to the field of corporate governance at present: the governance of risk management; the governance of executive compensation; and the skills, competencies and behaviours of board chairs and directors.

The focus on this second issue will be on four additional and emerging areas in the field of corporate governance: board value creation and leadership; technology literacy and the governance of enterprise technology; relationships between board information and firm value, and between board capital and strategy; and global dimensions of corporate governance, including demographic aspects of Brazilian boards of directors, and behavioural aspects of Irish and Canadian banking boards of directors.

We have eight articles to follow in this issue: (i) 'Forty Proposals to Strengthen the Board's Role in Value Creation; Management Accountability to the Board; and Board Accountability to Shareholders', by Professor Richard Leblanc; (ii) 'Impact of Board Leadership and Audit Quality on Disclosure Quality: Evidence from
Pakistan', by Safia Nosheen, doctoral candidate, Asian Institute of Technology, and Dr Supasith Chonglerttham; (iii) 'The Concept of the Functionality Grid and Technological Literacy', by Dr Ferdie Lochner; (iv) 'The Emerging Role of the Board of Directors in Enterprise Business Technology Governance', by Elizabeth L.H. Valentine, doctoral candidate at the Queensland University of Technology, and Professor Glenn Stewart; (v) 'Is Information on Boards Useful for Investors' Appraisal of a Firm's Value?', by Professors Sébastien Deschênes, Miguel Rojas and Tania Morris; (vi) 'Board Capital and Strategic Turnaround: A Longitudinal Study', by Professors Eduardo Schiehll and Louise Côté, and Ms Line Courtemanche; (vii) 'Corporate Governance: A Panoramic View of Brazilian Boards of Directors', by Talles Vianna Brugni, doctoral candidate at University of São Paulo, and Professors Patrícia Maria Bortolon, José Elias Feres de Almeida and Patrícia Krauss Serrano Paris; and (viii) 'Board Behaviours: Bringing Change in the Bank Boardroom', by Mary Halton, doctoral candidate at University College, Dublin.

Each article is described below, editing the drafting that the authors have provided and including a brief description of each author's background. We conclude with remarks by me at the end, and a thanking of reviewers. The length of the summaries below is unrelated to the articles themselves, and the articles do appear in an order. The first article refers to revisions to public company boards to focus more on value creation and less on compliance, written by an academic and governance lawyer. 
The second article to follow hones in on the effect of chair and CEO duality (including its negative moderating influence), ownership concentration and audit quality upon governance disclosure. Articles three and four both speak to the governance of information literacy, from a practitioner and an academic viewpoint. Articles five and six, written by academics address relationships between board size, independence and compensation, and shareholder appraisal of firm value; and draw on a longitudinal case study on the dynamic relationships between human and relational capital of the board, firm strategy and organizational environment. The remaining articles seven and eight address the independence, competencies and skills of individual directors, with the first article focusing mainly on structural variables of Brazilian directors, drawing on archival data, and the second article focusing more on behavioural variables such as behaviour and capacity to challenge, drawing on director interviews in two countries (Ireland and Canada) whose banks and banking sector performed differently before the financial crisis.

Note to the practitioners selected by me may have academic and writing leanings, and the academics may have practitioner and advisory leanings. This mutual overlap also bodes well for the articles, as the academics may bring structure, independence and rigour and the practitioners may bring experience, networks and application.

We now begin, with the first two articles addressing the value creation role of the board, and the impact of board leadership and audit quality on disclosure.

1. Forty Proposals to Strengthen the Board's Role in Value Creation, Management Accountability to the Board and Board Accountability to Shareholders The 40 recommendations within this article are based on, in no particular order: interviews with activist investors, private equity leaders, directors and CEOs; advisory work with regulators; assessments of leading boards; expert witness work; academic and practitioner literature and regulations in other countries; director conferences and webinars; lectures that the author delivered to the Institute of Corporate Directors and Directors College; discussions in the author's LinkedIn group, Board and Advisors; and research the author is conducting with Henry D. Wolfe on Building High Performance Boards.

The recommendations are organized into three groupings, as follows: (i) Increase board engagement, expertise and incentives to focus on value creation (proposals 1-19); (ii) Increase director independence from management, and management accountability to the board (proposals 20-30); and Increase director accountability to shareholders (proposals 31-40).

Several recommendations may result in significant restructuring and change in how a public company board operates, functions, is composed, engages and focuses. Boards are free to accept, reject or modify any recommendation. The author shares his proposals, based on the state of the field, particularly developments in the last year or two, involving, in particular, shareholder activist activity upon Canadian companies and interviews with activist shareholders.

Richard Leblanc is an Associate Professor, Governance, Law and Ethics, at York University. He teaches at Harvard University in the summer session and is a Strategic Advisor at the Institute for Excellence in Corporate Governance, University of Texas at Dallas. $\mathrm{He}$ is a governance lawyer and professional advisor, regularly advising leading boards of directors across industry sectors.

2. Impact of Board Leadership and Audit Quality on Disclosure Quality: Evidence from Pakistan Second, this article explores impact of governance characteristics on disclosure quality in an emerging economy of Pakistan. Multiple regression technique is used to analyse the data. The regression results support the agency theory and show that CEO duality (where the CEO also is chair of the board) 
is negatively related to disclosure quality, whereas ownership concentration and audit quality are positively influencing disclosure quality. More importantly, this article finds, from an interaction term in the regressions, that if CEO duality exists, ownership concentration becomes an adverse effect on disclosure quality. This suggests a strong negative influence of CEO duality on the disclosure practices in Pakistan.

This study is important for academicians and policymakers to understand how corporate governance influences listed firms in disclosing information. The results provide an important insight for academicians for further research and for policymakers to develop effective disclosure policies to alleviate the information asymmetry problem.

Safia Nosheen is a doctoral candidate at the School of Management, Asian Institute of Technology, in Thailand, and a Lecturer at Gomal University, Dera Ismail Khan, Pakistan. Supasith Chonglerttham is a Senior Instructor at the School of Management, Asian Institute of Technology, Thailand.

Next, we explore information technology, and more specifically technology literacy (or lack thereof) within boardrooms, and its impact upon corporate governance, in the two articles to follow.

3. The Concept of the Functionality Grid and Technological Literacy

Technology progresses in leaps and bounds, at the same time becoming more complex, and most often requires major investments long before any dividend is yielded. A major stumbling block, however, in fully leveraging the latest technological innovations and sensibly investing in these new technologies for the sake of profitability, societal well being and the environment, is a widespread and deep-seated lack of understanding of the basic tenets of modern technology. Neither fully explored nor well understood, this problem is known among interested parties as a manifest lack of technological literacy, and it poses a major problem from a boardroom and governance point of view. In response to this problem, this article introduces a concept colloquially known as the 'functionality grid', and demonstrates empirically how this concept can help to improve technological literacy across society, but especially at the primary stakeholder level, that is, that of technology decision makers in boardrooms and those C-level executives reporting to them. More specifically, the functionality grid offers to technology decision makers a panoramic overview of the full set of technological pathways, and at the same time enables a deeper analysis of the basic essence, the individual actions, and the specific productivity outcomes of individual technological innovations. It is, therefore, appropriate that this article concludes with a number of boardroom recommendations towards practical use of the functionality grid to help technology decision makers making the best technology investment decisions for sustainability's sake.

Ferdie Lochner is Head of IT Finance at the City of Cape Town, South Africa, and an independent technology analyst. He focuses on tracking and understanding new technologies appearing on the technological horizon, with a specific interest in the overall sustainability, lifecycle costs and governance of these technologies. He is a member of the Institute of Directors, writes for the Institute of Futures Research, mentors MBA and $\mathrm{PhD}$ students and lectures.

4. The Emerging Role of the Board of Directors in Enterprise Business Technology Governance

Next, we continue to explore technology literacy. With unprecedented changes being brought about by the nexus of mobile and cloud technologies, social media and big data, more than 80 per cent of boards of directors could be lacking the skills and knowledge to effectively govern business technology and realize strategic gains and financial returns at the enterprise level.

Although director awareness of the need for skills in enterprise business technology 
governance (EBTG) is growing, this literature review-based research identifies a significant gap between the stated importance of business technology, actual involvement in EBTG, and in having the right skills, knowledge and experience within boards to effectively use information and govern enterprise business technology. A finding is that awareness is high, but action within boards to recruit or develop the required expertise very low or non-existent, on a global scale.

Boards of directors may appear to have done well in leading and governing firms without IT expertise among their ranks; however, competitive, financial and reputational risk is increased if boards fail to recognize their role in governing technology and information as assets and in removing barriers to decision quality through their enterprise governance. Further, there is very little extant research in the area of board EBTG competence. However, noted academics (for example, Carter and Lorsch, 2004; Leblanc and Gillies, 2005) emphasise that if directors don't have reasonable appropriate strategy matching skills, knowledge and experience, in this case technology, they will be flying blind when it comes to the big strategic issues facing their companies. Increasingly, frustrated on a range of fronts, industry commentators go as far as declaring many board directors simply haven't a clue when it comes to EBTG, are frequently ageing, and from a pre-digital era, and can no longer afford to ignore, delegate or avoid business technology-related decisions.

Therefore, in order to address identified gaps and areas of risk, the authors' objective is to help boards, and those academics, practitioners and peak bodies who support them, to understand the future focus of EBTG, the board's role in this governance process, barriers to effectiveness in this area, and where risks are increasing. The authors describe the emerging BT environment, summarize the research on the extent to which boards are involved in EBTG and suggest why boards need to be competent in EBTG. The authors situate their work amidst the nexus of technology forces, and modernize current definitions. They outline corporate governance in this context, providing a new definition of EBTG, and conclude with practical suggestions, offering an integrated model and four outcomes that boards might focus on to ensure the organizations they govern are not left behind by those led by the upcoming new breed of technology-savvy leaders.

Elizabeth Valentine is a doctoral candidate at Queensland University of Technology. She holds an MBA from Henley (United Kingdom) and has been a successful chief executive, company director, business consultant and advisor in the use of technology, to both public and private sector enterprises.

Glenn Stewart is Professor of Information Technology, Information Systems School, Queensland University of Technology. His research interests include IT leadership, cultural influences on enterprise systems and global business process management projects, and the relationship between the CIO and the business leadership team. He is currently leading research on enterprise architectures methods supporting business IT investment and governance.

Both of the foregoing articles are persuasive articles that indicate the importance of technology literacy within boardrooms.

We now turn to two academic articles distilling particular relationships: the first explores the empirical relationship between board information on: independence; board size; stock compensation and ownership; and director tenure, and, in turn, investor assessment of firm value; and the second article is a case study on the relationship between human and relational capital of a board, firm strategy and the organizational environment. 
5. Is Information on Boards Useful For Investors' Appraisal of a Firm's Value?

Financial scandals, such as those of Enron, WorldCom and Nortel, have incited many investors to question the capacity of company boards to act as protecting bulwarks of their interests. This research intends to examine if investors consider themselves to be better served by boards with certain characteristics. If so, these boards would create value for investors by means of a greater demand for the firms' shares.

The characteristics examined in the article are: the independence of the Board of Directors; board size; the importance of stock-based remuneration for directors; the average number of tenure in years for directors; as well as the directors' ownership of the firms they serve. The role of the above mentioned board traits was investigated using data from the largest public Canadian firms over the period 2005-2010.

The authors' conclusion is that investors value firms with boards exhibiting higher ratios of stock-based remuneration of directors; a higher average of tenure years by directors; and a higher firm ownership by directors.

In consequence, boards of directors wishing to present a positive, reassuring view for investors should adopt these characteristics. Moreover, because the identified traits are connected with higher company valuation through lower equity cost, securities regulators, stock exchanges, institutional investors and shareholder rights activists should advocate that firms include in their by-laws measures leading to the implementation of a minimum value of stock-based remuneration, to a lower turnover rate of the Board of Directors, and to a higher level of board directors' ownership in the firms they serve. Sébastien Deschênes is an Associate Professor and Director in the Accounting Department at Université de Moncton. Miguel Rojas is an Assistant Professor in the Accounting Department at Université de
Moncton. Tania Morris is an Associate Professor and Acting Coordinator and Jeanne and J.-Louis-Lévesque Chair of Research on Financial Management at Université de Moncton.

6. Board Capital and Strategic Turnaround: A Longitudinal Case Study

In this article, the authors examine, through a 10-year longitudinal case study of a publicly traded global transportation company, the dynamic relationships between board capital (human and relational capital), firm strategy and organizational environment.

Building on resource dependence theory, the authors show how the firm adapted the human and relational resources provided by the board of director in response to organizational strategies and the changing contingencies of the organizational environment. Their study refines and extends Hillman and Dalziel's (2003) board capital taxonomy and contributes to the corporate governance literature on director's advisory role.

This study provides timely and practical insights into the issue of effective board composition. Boards are now expected to function with far more transparency and accountability than they did even a decade ago and, at the same time, to be more attuned to complex issues such as risk management, technological change and environmental concerns.

Therefore, the article by the authors brings practice and research on board composition into a sharper focus, in times where executive recruiters and governance consultants advise boards to develop a skill matrix as a way of gathering a broad range of expertise required for boards to perform effectively. In light of their findings, investors and policymakers are invited to consider expertise and experience requirements for an effective service task when nominating board members and developing board composition rules.

Eduardo Schiehll is an Associate Professor of Accounting at HEC Montréal. His research interests lie primarily in the areas 
of corporate governance and management control systems design. Louise Côté is Full Professor of Accounting and Director of Academic Affairs at HEC Montreal. Her research and teaching interests lie primarily in governance, management control systems and strategic management. Line Courtemanche is Development Advisor at Desjardins Group Monitoring Office.

Finally, we have two articles on the competency, skills and behaviours of individual directors, including: the challenges of having a majority of independent directors, independent leadership and director independence from controlling shareholders on Brazilian boards of directors (the first article's introduction to follow); and, drawing on qualitative interviews with Irish and Canadian bank directors (and other stakeholders), the second article (introduction to follow) explores behaviour within boardrooms and, in particular, directors' willingness and ability to challenge management and each other.

7. Corporate Governance: A Panoramic View of Brazilian Boards of Directors

The authors provide a descriptive overview of qualities of boards of directors in Brazil.

Although Brazil offers low minority shareholder protection, some initiatives provide incentives for public companies to follow good practices of corporate governance. For example, the Brazilian Institute of Corporate Governance developed the first Brazilian Code of Corporate Governance Practices without legal enforcement, and the special listing segments created in 2001 by the São Paulo Stock Exchange (Bovespa) demanding better corporate governance practices beyond the legal requirements.

The authors analysed in this study 315 firms' reports in 2010 from a new database developed by Brazilian Securities Exchange Commission. The authors show how, approximately, 30 directors' characteristics are distributed among Brazilian public companies, including personal characteristics and functioning of boards, such as evaluation mechanisms, meeting frequency, independence and special committees.

More than 40 per cent of companies observed are listed in one of the special listing segments of Bovespa. Despite some good corporate governance practices appear to be widespread among companies, having a majority of independent members on Boards and the separation of chair and CEO positions is still a challenge. More than 75 per cent of directors are named by the controlling shareholder(s), a practice that does not help to alleviate the conflicts of interests between controlling and minority shareholders in an environment characterized by ownership concentration.

The directors' profiles show that the level of postgraduate education and executive training are low. Approximately, 21 per cent of directors have some postgraduate education. Women represent less than 10 per cent of directors.

This scenario shows that boards of directors in Brazil need an improvement in directors' independence and academic background. The main challenges, when compared with developed economies, are in transforming voluntary practices into legal requirements to achieve higher levels of independence in boards of directors.

Talles Vianna Brugni is a doctoral candidate in Accounting and Control at University of São Paulo. He is a researcher in the area of corporate governance and earnings quality in Brazil. He is currently researcher at the Federal University of Espírito Santo and a teaching assistant in Cost Analysis at University of São Paulo. Patrícia Maria Bortolon is an Associate Professor of Accounting Department at Federal University of Espírito Santo. She holds a PhD in Finance from the COPPEAD Management School at Rio de Janeiro Federal University. José Elias Feres de Almeida is an Associate Professor of Accounting Department at Federal University of Espírito Santo. He holds a $\mathrm{PhD}$ in Accounting and Control at University of 
São Paulo. He is a Member of the Specialists Committee of Group of Latin-American Accounting Standard Setters and of the IFRS Group of Brazilian Federal Accounting Council. Patrícia Krauss Serrano Paris holds an $\mathrm{MSc}$ in Accounting, and is a Governmental Manager, Professor of Business Administration and researcher.

8. Board Behaviours: Bringing Challenge in the Bank Boardroom

Finally, this article discusses how challenge matters for bank non-executive directors and what the potential implications are for corporate governance. Drawing on interviews with chairs, board members and others from a notoriously closed culture, the article questions how these stakeholders view challenge, whether these views are aligned to boardroom behaviours, and why gaps arise between views espoused and behaviours evidenced.

As part of a wider research project on bank board behaviours, a qualitative case study approach was adopted that centred on understanding the views of people with direct experience of bank boardrooms. As Ireland and Canada operate similar governance regimes, but have had very different experiences of the recent global financial crisis, views from these two locations were gathered in order to gain insight into boardroom dynamics and explore the possible corporate governance implications. Contributors comprised current and former bank chairs and non-executive directors, executives, regulators, other industry specialists and academics. In-depth semi-structured interviews with contributors allowed for exploration of the issues and yielded a significant amount of rich data about challenge, among other behaviours.

Findings indicate that although challenge is widely viewed both as important and as an influence on corporate governance outcomes, there is often a failure to embrace it fully in the boardroom. A number of factors are implicated in this mismatch between expectations and practice, including a director's own willingness and ability to bring challenge in this often complex business arena. The need for collective decision making and the ethos governing the board are found to constrain director action, at times even when directors have significant concerns about a particular issue. However, behaviours change in times of crisis.

In light of corporate governance, failures implicated in the recent global financial crisis, board effectiveness is a critical issue for systemically important banks and, by extension, for society in general. The findings are important for policy and practice in that they suggest the need to re-frame challenge within the boardroom and foster a culture where constructive challenge can thrive. They also make observations about the pressures of collective decision making and director willingness and ability to challenge.

This highlights the importance of recruiting non-executive directors with the right behavioural and technical competencies to be effective in their corporate governance role. The findings are also of academic relevance, adding to a relatively limited understanding of board behaviours and their implications for corporate governance. Further research is suggested, particularly in understanding how non-executives themselves perceive their role and how we can create the conditions, which support these directors in the effective discharge of that role.

Mary Halton holds an MSc in Executive Leadership from University of Ulster. She is currently in the final year of a $\mathrm{PhD}$ in Public Policy with University College, Dublin. She has held executive director roles in insurance in Ireland and has a number of years of experience in management roles with major banks in Canada and the United Kingdom. Her consulting interests are in governance, leadership, personal development and organizational change. She is a member of the governing council of Chartered Accountants 
Ireland and serves on its audit and risk committee. She is a non-executive director of a regulated Irish insurance company where she also chairs the audit committee.

\section{CONCLUSION}

All 16 authors of the above articles are sincerely thanked for their diligence and responsiveness in responding to the many edits I proposed, as well as those of other academics, thanked below, and bringing these articles to bear. They do represent a blend of academic and practice, emerging qualitative research and key issues now of concern to boards of directors, namely, value creation by boards, board leadership, technology literacy, share ownership, governance disclosure, the strategic role of the board, director independence from controlling shareholders, and directors' ability and willingness (or not) to challenge constructively within boardrooms.

The following individuals are sincerely thanked for their reviews of some of the more quantitative articles, in this and the preceding issue: Professor Yacine Belghitar, Cranfield
University; Professor Ruth Bender, Cranfield University; Professor Gilles Bernier, Université Laval; Professor Patrice Gélinas, York University; and Professor Jacques Grisé, Université Laval.

We hope you enjoy the quality of the articles herein.

\section{REFERENCES}

Carter, C.B. and Lorsch, J.W. (2004) Back to the Drawing Board: Designing Corporate Boards for a Complex World. Boston, MA: Harvard Business School Press.

Hillman, A.J. and Dalziel, T. (2003) Boards of directors and the firm performance: Integrating agency and resource dependence perspectives. Academy of Management Review 28(3): 383-396.

Leblanc, R. and Gillies, J. (2005) Inside the Boardroom. Ontario: Wiley \& Sons.

Richard Leblanc Special Edition Editor Law, Governance \& Ethics York University, Toronto, Canada 